\title{
Translating 'shame'. A translational approach (II)
}

\author{
Magda Jeanrenaud* \\ Faculty of Letters, "Alexandru Ioan Cuza" University, Bd. Carol I 11, 700506 Iaşi, Romania
}

\section{Article info}

History:

Received July 21, 2017

Accepted July 27, 2017

Published November 30, 2017

Key words:

lexical field

skopos theory

evaluation of translation

specialized text

translator's freedom

\begin{abstract}
Starting from the semantic and lexical sphere of the concepts of 'honte' (in French) and 'rușine' (in Romanian), my aim is to examine the way this word was translated into Romanian; for this purpose, my point of departure was a case study. To this end, I tried to elaborate a comparative translational study of Boris Cyrulnik, titled Mourir de dire. La honte (Éditions Odile Jacob, Paris, 2010) and of its Romanian translation, titled Mai bine mor decît să spun. Ruşinea (French translation by Valentin Protopopescu, Editura Trei, "Psihologia pentru toți” collection, Bucharest, 2012). Cyrulnik's text has a particularity: it oscillates between the specifics of a literary text and those of a specialized text. From this standpoint, his transposition challenges the functionalist theories of translation and mostly the skopos theory elaborated by Katharina Reiss and Hans Vermeer: it is interesting to analyse the way the translator "decodes" the "intentionality" of this type of text, ultimately a specialized text, and the way he decides to transpose its semantic and lexical sphere into Romanian.
\end{abstract}

\section{The lexical field of shame: a) effects of shame}

The fact that the translator did not study the dominant of this text (thus he failed to elaborate a hierarchy of his translational effort), that he did not focus enough on reconstructing in his translation the terminological grid around the concept of shame are also obvious in the way he chose to transpose the lexical field of this concept. The paraphrase, periphrasis, synonymy ended up extending the lexical field excessively and rendering it less specific than in the original text, implicitly.

For this type of text, the lexical field around the key-term, shame, is meant to construct and support the entire argumentative framework. The author of the text-this time clearly in his capacity as a specialistenumerates the effects of shame upon the ones affected by this trauma following events that had perturbed their existence significantly. Hence, he lists the following: malaise, fletrissure, fracas, and, most frequently, déchirure. The translator has to reconstitute this constellation of pain indicators, who become as many symptoms of pathology. However, the translator uses yet again synonymy massively, but he also chooses often the marked poetizing term that beatifies the lexical register, which estranges the text from its dominant function and provides it with a different coherence than the one embedded in the intentionality of the source text. In this respect, I will provide only a few examples in the following lines.

Malaise - one of the "untranslatable" terms of the French lexicon, according to the well-known Vocabulaire européen desphilosophies (subtitled Dictionnaire des intraduisibles) - denotes a dysfunction between soul and body; hence, its semantic sphere reverberates both towards "the networks of affect and passion" and of the physiological disorders; both at individual and at ontological and even "national", related to "origin" (Cassin, 2004, p. 750). The translator is the one who has to operate-by the context and the type of text to translate-a selection among the various semantic paths of the term. Furthermore, he has to maintain its coherence in similar contexts, where the use of synonyms would actually perturb reception. In the Romanian version, where malaise concerns a psychological state (not a physical sickness), a disturbance, it is translated by suferință in a general sense (where the combination with contagioas $a$ becomes

*Email address: mjeanrenaud@hotmail.com. 
Magda Jeanrenaud

inadequate) or by disconfort, or even by a frivolous indispoziție that mitigates the severity of the trauma that it expresses. Thus, "Le malaise n'est pas toujours provoqué par un effondrement traumatique" (p. 81) becomes "Indispoziția nu este totdeauna provocată de un colaps traumatic" (p. 76). The serious perturbation determined by shame generates very perceptible physical reactions: "Un adolescent rougit, évite le regard et bafouille de malaise" (p. 85); actually, se bîlbîie de tulburare [he is so troubled, he stammers], not "flecărește, spre a-și masca disconfortul" (p. 80).

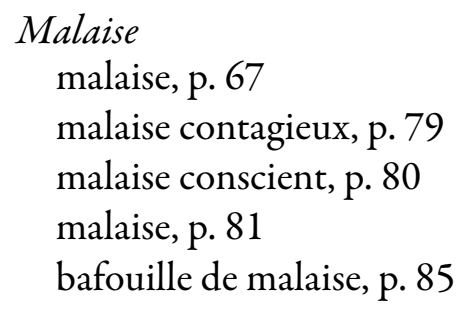

suferința, p. 62

suferință contagioasă, p. 73

indispoziție conștientă, p. 75

indispoziţia, p. 76

flecărește, spre a-și masca disconfortul, p. 80

Flétrissure-whose semantic sphere indirectly suggest the sign applied with a red-hot iron to the convicts in the public square during the French Old Regime-is a stigma, a term that the DEX is defined as dishonoring, a "shameful" mark that may be associated with infierare. Sparked by an intimate trauma, shame erupts under the look of the others: transposed either by alterări (p. 76) or by nefericire (p. 148), how could these flétrissures - the stigmas of "mărunte rușini ale vieții cotidiene" [small shames of daily life] (p. 76)-represent "punctul de plecare al moralei" [the starting point of morals], how could they provide the energy to combat the one that stigmatizes us, in order to liberate ourselves from shame?

\title{
Flétrissure
}

flétrissures, p. 81

flétrissure, p. 159

\author{
alterări, p. 76 \\ nefericirea, p. 148
}

Fracas - the shock of a violent fracture-that refers, very concretely, to the noise produced by it, is translated by tulburare, tumult, colaps, dezastru or by agresată, distrus, zdrobit, prăpăd; the occurrences of the equivalent tulburare, tulburat are numerous. However, tulburarea indicates a state of confusion quite far from the commotion expressed by the semantics of the source term and it pushed the lexicon towards a vague, general level (tulburarea may suggest convulsie, tumult, but not the other way around, too). Within the list of synonyms proposed by the dictionary Trésor de la langue française, trouble, the French equivalent of tulburare, is not even mentioned: all the equivalences (bruit, tempête, ouragan, grondement, agitation, déflagration, vacarme, etc) are related to an extreme "resounding" intensity. In its concreteness, the French term involves no ambiguity, no doubt.

Fracas

fracas, p. 8, două ocurențe

fracas, p. 72

fracas, p. 76

fracas, p. 93

le fracas, p. 111

fracas, p. 112

fracassés, p. 76

personne fracassée, p. 117

un fracas, p. 157

blessées, mais non fracassées, p. 158

fracassé, p. 174

le fracas de la guerre, p. 256 tulburare, tumultului, p. 8

tulburare, p. 67

tumult, p. 71

tulburărilor, p. 85

colaps, p. 102

dezastru, p. 104

tulburați, p. 71

persoana agresată, p. 109

colaps, p. 147

rănite, dar nu și distruse, p. 147

zdrobiţi, p. 161

prăpădul războiului, p. 235 
The most interesting case is that of the term déchirure, also translated using numerous equivalences: farîmițare, ruptură, sfișisiere, suferință, traumatism, destrămare, as if the translator feverishly sought for the most adequate term but failed to find it. Ruptură [rupture] - a more extended, thus more general term-records the most occurrences (though it is mostly used in the medical lexicon, mostly in contexts related to the rupture of various organs). Fractură [fracture] — which would suggest both concretely and figuratively a serious lesion-has no occurrence; destrămat and sfișiat suggest rather poetizing clichés than a specialized psychoanalytical lexicon. Socul traumatic [traumatic shock] is not among the versions considered by the translator, though it seems to be used in the specialized lexicon.

\section{Déchirure}

déchirure invisible, p. 64

déchirure, p. 68

déchirure traumatique, p. 72

déchirure affective, p. 79

déchirures, p. 80

déchiré, p. 80

déchirure traumatique, p. 87

la déchirure traumatique, p. 94

ma déchirure, p. 102

la déchirure, p. 132

déchirure traumatique, p. 157

déchirure, p. 165

déchirure, p. 165

déchirer le lien, p. 164

déchiré, p. 69

déchiré, p. 115

se déchire, p. 183

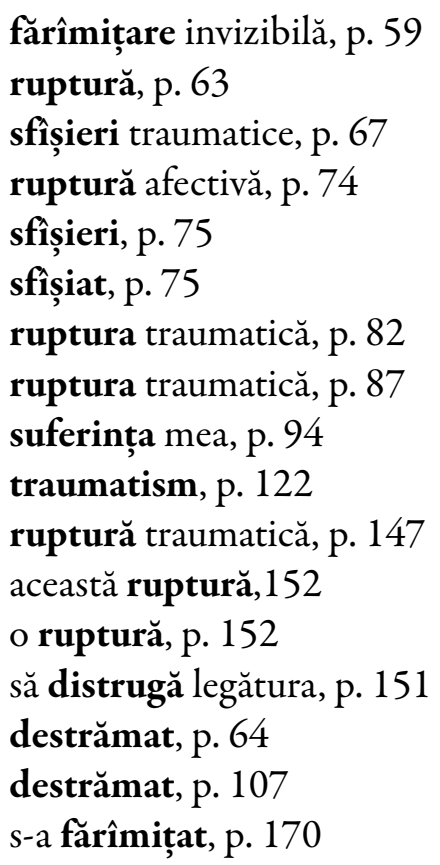

This pressure of finding synonyms gradually becomes more important than the importance of constructing, in the target language, the lexical field of the concept of shame. Instead of grasping the physical component of the trauma of shame, the translator transposes, for instance, les filles honteuses (p. 148) into fete făcute de rîs (p. 138), in a context where the author talks about the physical pain of women who are induced shame, shame of their own sex, in order to make their submission easier. This sentence is part of a relevant subchapter titled in the original Fonction socialisante de la souffrance physique (p. 147), but in Romanian it becomes Funcția socializantă a suferinței psibice...

\section{Fonction socialisante de la souffrance physique // Funcția socializantă a suferinței psibice}

La pensée automatique consiste à dire que, puisque les garçons battus et les filles honteuses finissent par prendre la place subalterne qu'on veut leur attribuer, il suffit de supprimer toute douleur et toute honte pour qu'ils s'épanouissent et deviennent heureux (p. 148).
Gîndirea automată constă în a spune că, deoarece băieții bătuți și fetele făcute de rîs sfîrșesc prin a ocupa locul subaltern care li se atribuie, ar fi suficient să suprimăm orice durere și rușine pentru ca ei să înflorească și să devină fericiți (p. 138).

I do not suggest here that I support unconditionally a view of translation based on the supremacy of the signifier, but the decision to crumble the specialized lexicon in translation should have a justification, which I failed to find in this case. Concerning this lexicon, an excessive and unjustified dispersion only undermines the specific of the text: "synonymization" is not and cannot be a universal translational principle. On the other hand—and this is the essential point—, by disseminating a lexicon that aims to become 
a terminology, the very topic of the book (shame as trauma, as physical and mental wound) tends to become a metaphor that accentuates the essayistic and narrative side, to the detriment of a psychoanalytical journey destabilized by the lack of a stable conceptual support. However, this is the main topic of the book!

Therefore, some researchers posit that the specificity of translation techniques in case of humanities discourse is the practice of various techniques for the "general language" and terminological lexicon. While for transposing the first, the translator can use the technique of equivalences, for the latter he must use correspondences systematically. Whenever possible, he must use corpuses of related terms by derivation or etymology (similarly to Saussure, a long time ago, when he named the sides of the linguistic signs). Thus, the translator should differentiate the terminology, the array of key-concepts within the text to translate, which he would subsequently have to transpose into the target language using strictly the term he decided-either the literal translation or a neologizing term, if he had enough courage to use it (Cassin, 2004, p. 298). In other words, whereas the "general" lexicon must be rendered using "idiomatic" procedures, the transposition of terminology would be done literally, "imitatively". In this case, it may be concluded that the use of literal translation and of loan technique-in other words, the dependence on the terms used in the source text-may represent a particularity of translating humanities-specific discourses. If the use of such procedures turned out to be recurrent, then it can be stated that in that type of text, the desideratum of textual cohesion tends to be treated differentially. Thus, the specialized lexicon is transposed by fully observing the density in the source text, while general lexicon admits and even requires translation by equivalence.

Unii cercetători consideră astfel că specificitatea tehnicilor de traducere în cazul discursului științelor umane constă tocmai în practicarea unor tehnici diferite pentru „limba generală” și lexicul terminologic, iar dacă pentru transpunerea celei dintîi se poate apela la tehnica echivalențelor, pentru cel din urmă se impune utilizarea sistematică a corespondențelor, recurgîndu-se, oriunde este posibil, la corpusuri de termeni înrudiți prin derivare sau etimologie (cum procedase cîndva Saussure în denumirea fețelor semnului lingvistic).Traducătorul ar trebui astfel să deosebească terminologia, evantaiul de concepte-cheie din textul de tradus, pe care ar urma apoi să le transpună în limba țintă menținînd cu strictețe termenul corespunzător pe care l-a decis, fie că este vorba de o traducere literală, fie că a îndrăznit o neologizare (Cassin, 2004, p. 298). Cu alte cuvinte, dacă lexicul „general” ar trebui redat prin procedee „idiomatice”, transpunerea terminologiei s-ar face pe cale literală, ,imitativă”, caz în care am putea trage concluzia că folosirea traducerii literale și a tehnicii împrumutului, altfel spus dependența vizavi de forma termenilor textului sursă ar putea reprezenta o particularitate a traducerii discursului științtelor umane. Dacă folosirea acestor procedee s-ar dovedi recurentă, atunci am putea afirma că în acest tip de text, dezideratul coeziunii textuale are tendința de a fi tratat în mod diferențiat, lexicul specializat fiind transpus cu respectarea integrală a densităţii din textul sursă, în timp ce lexicul general admite și uneori chiar pretinde traducerea prin echivalență.

\section{The lexical field of shame: b) predication of shame}

At a syntagmatic level, shame develops in our text a combination focused on a relatively small number of verbs, which-through their recurrence-create a semantic network meant to specify, delimit and explicitate not only the "topic", but also the trauma of shame. Whereas it may not be very poor, the lexicon of shame is actually not very rich in Cyrulnik's book, because this is not his intention. In many cases, however, the translator dilutes the lexicon in the Romanian version, though the main verbal axes that determine shame can be transposed into Romanian by correspondence. In fact, this terminological fluctuation indicates that the translator failed to perceive the existence of a lexicon aiming to become a terminology and that he treated it like a "current" lexicon, where variation would be justified, á la limite, only by the rejection of "literalism". We may thus decipher his "project", his view of the translation for this type of text, but his view no longer coincides with the intentionality of the source text, insofar as 
the translator extends the technique of "idiomatizing" to the whole text, as if he had failed to grasp the hierarchy of textual levels, specialized text and essay, (specialized text being the primary level).

The text follows mainly three verbal axes, all based on the principle of lexical economy. The syntagmatic axis (of combinations in presentia) makes up the framework around the core concept of shame. The first verbal axis circumscribes shame as a feeling, then as a provoked trauma that can end up destroying the one affected by it: the verbs related the individual perception of shame are the following, some of which (ressentir, eprouver, sentir) are almost synonyms:

avoir honte - ressentir la honte - éprouver de la honte - se sentir honteux - rendre honteux - faire honte - provoquer la honte - mourir de honte

The dramatic consequences of the trauma of shame are organized around the silence to which it constraints the subject, who cannot speak it for fear of the isolation to which telling it would condemn him.

$$
\text { la honte fait taire - dire la honte - la honte fait fuir }
$$

Finally, the third axis concerns the effort of liberation, of escaping trauma, made by the individual who wants to save himself: this axis, too, features a limited number of almost synonymous verbs:

$$
\text { s'affranchir de la honte - se libérer de la honte - sortir de la bonte - se sauver de la honte }
$$

Besides the times when these verbal structures were translated by correspondence, it is worth underscoring an over-diluting tendency of the translator: he uses an inventory of synonymies that exceeds the reduced inventory within the source text. Its function is actually to consolidate a certain lexicon by concentrating it, not to disperse it by disorganizing it. Sometimes, the translator's effort to find synonyms leads to rhetorizing, inadequate or downright mistranslated constructions: îmi este ruşine că mi-a fost rușine, with all its redundancy present also in the source text, is not the same as a-țifi ruşine de propria ruşine; that it is possible să-ți fie rușine că locuiești in a very luxurious apartment does not mean that you have concluded that faptul ar fi un lucru de rușine; to say that ți-e ruşine is not the same as a-ți mărturisi ruşinea; a-ți fi ruşine also does not mean a descoperi ce înseamnă să trăiești cu ruşinea în suflet, which may be adequate for a literary text, nor does it mean a ți se face rușine, nor a o resimți, nor a o trăi, and much less a o experimenta. In several occurrences, I also find disputable the assimilation between a-i fi rusine and a se rușina. The avoidance of repetitions-a procedure specific to this type of text-leads to the transformation of "on peut avoir honte sans raison d'avoir honte" (p. 80) into a construction lacking both elegance and clarity: "ne poate fi rușine fără să avem motiv pentru asta" (p. 75).

\title{
9.1. Avoir bonte
}

Un souvenir d'enfance // $O$ amintire din copilärie

qu'on pouvait avoir honte d'habiter j’ai honte d'avoir eu honte

că ar fi un lucru de rușine să locuiesc mi-e rușine de rușinea mea de-atunci

\section{La bonte et son contraire // Ruşinea și opusul ei} fier d'avoir honte en disant qu'il avait honte se mîndrea cu faptul de a fi resimţit rușine mărturisindu-și rușinea

\author{
Honte sexuelle // Rușinea sexuală \\ elle avait honte
}

\author{
Honte ou culpabilité? // Rușine sau vinovăție? \\ alors elle a honte
}
descoperise ce înseamnă să trăiești cu rușinea în suflet

şi-atunci i se face rușine 
Lilliput, star de la honte // Liliputanul, vedeta rușinii

nous n'avons pas honte pe loc nu resimțim rușine

La honte peut durer deux heures ou vingt ans // Ruşinea poate dura două ore sau două decenii on peut avoir honte sans raison d'avoir ne poate fi ruşine fără să avem motiv pentru honte asta n'ont pas honte nu se rușinează că avaient presque honte aproape că au trăit sentimentul rușinii

Le déni, une légitime défense morbide // Negarea, o legitimă apărare morbidă on a honte de ne pas en avoir souffert îi va fi rușine din pricină că această suferință nu s-a produs

Les animaux ont-ils honte? // Animalelor le este rușine? avait honte se ruşinase

La manière d'aimer est un mode de socialisation // Felul in care iubim este o modalitate de socializare l'enfant eut honte de ce qu'il était sous le re- copilului i se făcu rușine de felul cum arăta gard de cette dame

Bonheur et pulsions. Honte et morale // Fericire și pulsiuni. Rușine și morală aucune raison d'avoir honte nici un motiv să experimenteze rușinea

Affectivité et performances scolaires // Afectivitate și performanțe școlare

on n'a pas honte de travailler dans une méd- nu e motiv de ruşine să lucrezi într-o medina ina de pauvres de săraci

Nègres, zoos et hôpitaux psychiatriques // Negri, grădini zoologice și spitale psibiatrice la culture a à son tour honte sistemul cultural ajunge să resimtă rușine

Les sans-honte // Cei färă ruşine

n'ont jamais honte

comment voulez-vous avoir honte

nu trăiesc niciodată rușinea

cum vă închipuiți atunci că acesta va simți rusine

Morale, perversions et pervertis // Morală, perversiuni și pervertiţi n'ont jamais honte nu li se face niciodată rușine

\subsection{Faire bonte}

Inexplicably, faire honte seems to have determined the greatest fluctuation in the list of equivalences: $a$ trezi, a produce, a stîrni, a face să, a inculca. Again, the only justification is the well-known resistance of translators to repetitions, which would allegedly question their own skills of mastering the target language.

Transparence du honteux // Transparența celui care suferă de ruşine

fait honte au nécessiteux trezește rușinea celor nevoiaşi

Le „je” n'existe quauprès d'un autre // „Eul” nu există decît în raport cu un altul pouvoir de me faire honte puterea de a-mi produce rușine 
Un monde où tout fait honte // O lume în care orice stîrnește rușinea
faire honte
a trezi rușinea
tout fait honte
orice produce rușine

Fonction socialisante de la souffrance physique // Funcția socializantă a suferințtei psibice

leur faire honte să li se inculce rușinea

Les Noirs et l'étoile jaune // Negrii și steaua galbenă

c'est la signification qui fait honte semnificația este cea care stîrnește rușinea

Quand la servitude renforce // Cînd supunerea întărește

pouvoir de lui faire honte puterea de a o face să se rușineze

La violence au théâtre de l'honneur // Violența în teatrul onoarei

il n'a pas le pouvoir de faire honte nu are puterea de a stîrni rușinea

Le pouvoir des chaussettes // Puterea ciorapilor

le pouvoir de nous faire honte puterea de a ne stîrni rușinea

\subsection{Mourir de honte}

The height of this axis-which leads to mourir de honte - did not practically entail any paraphrase, except for the inappropriate phrase rusine letală - which I have analysed before and which destroys the connnections between the title and the text itself_-and for two occurrences, "îmi vine să mor de rușine" (p. 75) and "le vine să moară de rușine" (p. 177) which inexplicably attenuate the fulfilled action in "je meurs de honte" (p. 80) and "ils meurent de honte", respectively (p. 190).

Un souvenir d'enfance // $O$ amintire din copilärie nous serions morts de honte cette mort de honte am fi murit de rușine l'enfant mourait de honte această rușine letală copilul murea de rușine

Le détracteur intime // Detractorul intim je vais mourir de honte voi muri de rușine

La bonte et son contraire // Ruşinea și opusul ei mourait de honte

murea de rușine

Transparence du honteux // Transparența celui care suferă de ruşine

meurt de honte sous son regard moare de rușine în faţa privirii acesteia comme d'autres meurent de honte cum alții mor de rușine

La réussite, un masque de la honte // Reuşita, o mască a ruşinii le mort de honte cel care moare de rușine

Les maîtres du rêve et le miroir crotté // Maeștrii visului și oglinda mînjită mort de honte, encore une fois mai moare încă o dată de rușine 
La honte peut durer deux heures ou vingt ans // Ruşinea poate dura două ore sau două decenii elle mourrait de honte ar muri de rușine pour un rien, je meurs de honte pentru un nimic îmi vine să mor de rușine

Le cinéma intérieur de notre abjecteur de conscience // Cinematograful lăuntric al denigratorului de conștiință

ils mourraient de honte

ar muri de rușine

il serait mort de honte

ar fi murit de rușine

Affectivité et performances scolaires // Afectivitate și performanțe școlare

était mort de honte parce qu'il avait échoué murea de rușine deoarece picase examenul au concours d'entrée dans une grande école de admitere într-o universitate quand ils échouent, ils meurent de honte cînd se confruntă cu eșecul, le vine să moară de rușine

Nègres, zoos et hôpitaux psychiatriques // Negri, grădini zoologice și spitale psibiatrice mortes de honte et de désespoir meurt de honte et de désespoir moarte de rușine și disperare moare de rușine și disperare

L'bymen est un discours social // Himenul este un discurs social
feraient mourir de honte
ar face să moară de rusine

Quand la violence était morale // Cînd violența era morală un homme meurt de honte un bărbat moare de ruşine plutôt que mourir de honte decît să moară de rușine

Quand la servitude renforce // Cînd supunerea întărește mourait de bonte murea de ruşine

La violence au théâtre de l'honneur // Violența în teatrul onoarei que de mourir de honte decît să mori de ruşine

Morale, perversions et pervertis // Morală, perversiuni și pervertiți
morts de honte
ar fi murit de rușine

\subsection{Ressentir - éprouver - provoquer la honte; dire la honte - s'affranchir - se sauver - se libérer de la bonte}

This axis may suggest some variation to the translator because it is also features in the source text. However, it exceeds the one of the source text again and it includes a certain number of inadequate phrases, such as a nutri ruşine or a vădi rușine. Hence, provoquer in provoquer la honte is translated by: a stîrni, a declanșa, a genera; éprouver in éprouver la honte is transposed by: a încerca, a vădi, a fi, a se simți invadat, a prezenta, a experimenta, a resimți, a avea, a arăta, a suferi, a simți, a da dovad $\breve{a}$, a fi incercat; dire in dire la honte by: a afirma, a mărturisi; ressentir din ressentir la honte: a nutri, a i se face; s'affranchir in s'affranchir de la honte by: a se elibera, a obține; se sauver in se sauver de la honte by a se salva; éponger in éponger la honte by a se scutura; śen sortir by a scăpa; sortir in sortir de la honte by: a depăși, a ieși; se libérer by a se elibera. 
Un souvenir d'enfance // $O$ amintire din copilärie ne provoquait pas de honte

nu era de natură să stîrnească ruşinea

Alain... s'est tué... sans jamais avoir éprouvé le moindre sentiment de honte

Alain... s-a sinucis... fără să fi încercat vreodată cel mai mărunt sentiment de ruşine

La honte et son contraire // Ruşinea și opusul ei en disant qu'il était honteux, il exprimait sa fierté

en disant qu'il avait honte setiment de honte que je ressens en éprouvant un peu de honte on peut donc éprouver une honte à montrer de soi une image

afirmînd că-i este ruşine, Stanislas îş̣i exprima mîndria mărturisindu-și rușinea sentiment de rușine pe care-l nutresc vădind puțină rușine este posibil să ne fie rușine a ne arăta nouă înşine o imagine de sine

Transparence du honteux // Transparențta celui care suferă de ruşine s'affranchir de la honte elibera de rușine s'affranchir de la honte elibera de rușine se sauvant ainsi de la honte salvîndu-se astfel de ruşine

La réussite, un masque de la honte // Reuşita, o mască a ruşinii s'affranchir de la honte a obține eliberarea de rușine s'affranchir de la honte să se elibereze de rușinea

Les maîtres du rêve et le miroir crotté // Maeștrii visului și oglinda mînjită provoque la honte stîrnește rușinea

Plus le malheur est grand, plus la victoire est glorieuse // Cu cît nefericirea este mai mare, cu-atît victoria este mai glorioasă

épongent le plus facilement leur honte s'affranchir de la honte s'affranchir de la honte s'en sortir

Honte ou culpabilité? // Ruşine sau vinovăție? le petit garçon avait ressenti la honte s'affranchir de la honte éprouvent la honte se scutură cel mai ușor de rușine

elibereze de rușine să se elibereze de rușine a scăpa de rușine

băiatului i se făcuse rușine a se elibera de rușine se simt invadați de rușine

\section{Lilliput, star de la honte // Liliputanul, vedeta ruşinii}

provoque la honte

generează rușinea

\section{La honte peut durer deux heures ou vingt ans // Ruşinea poate dura două ore sau două decenii} se libèrent de la honte, ils ont honte d'avoir se eliberează de rușine, li se face rușine că le-a eu honte fost ruşine nous éprouvons notre passé avec honte ou ne prezentăm trecutul cu rușine sau mîndrie fierté

Le déni, une légitime défense morbide // Negarea, o legitimă apărare morbidă sort de la honte pour entrer dans la fierté a depășit rușinea pentru a descoperi mîndria 
On se libère de la honte en modifiant l'âme des autres // Ne eliberăm de ruşine în măsura în care le schimbăm celorlalți sufletul

se libérer de la honte elibera de rușine

On se libère de la honte en agissant sur n'importe quel point du système // Ne eliberăm de rușine acționînd in oricare punct al sistemului

l'éprouvé qui prépare à la honte

éprouver une autre source de honte situaţia care pregătește sentimentul rușinii

experimenta o altă sursă a rușinii

fără a resimți un sentiment de rușine

\section{L’immigration, chance ou malchance sociale? // Imigrația, șansă sau neşansă socială? \\ éprouvent la honte incearcă un sentiment de rușine}

Affectivité et performances scolaires // Afectivitate și performanțe școlare
provoque la honte
declanșează rușinea

Les Noirs et l'étoile jaune // Negrii și steaua galbenă

éprouvent un sentiment de honte planté au au un sentiment de rușine sădit în adîncul sufond d'eux-mêmes fletului

Quand la servitude renforce // Cînd supunerea întărește honte d'éprouver rușinea de a simți

Quand le réel est différent du récit de ce réel // Cînd realitatea este diferită de discursul acestei realități sortir de la honte pentru a ne elibera de ruşine peut-on dire „sortir de la honte” difficile de sortir de la honte sortir de la honte putem oare să spunem „să ieșim din rușine” foarte greu să depășim rușinea depăşirea ruşinii

Les sans-honte // Cei fară ruşine des individus qui n'éprouvent ni honte ni indivizi care nu arată nici ruşine, nici fierté mîndrie de ne jamais se sentir honteux să nu se simtă nicicînd rușinați la honte „éprouvée...” rușinea „resimțită...” „...ceux qui éprouvent trop de honte...” on n'éprouve la honte que ces hommes n'éprouvent pas de honte „cei care vădesc prea multă rușine...” nu suferim de ruşine decît acești oameni nu resimt rușine

Morale, perversions et pervertis // Morală, perversiuni și pervertiți éprouver de honte ou de culpabilité fără a da dovadă de rușine sau vinovăție

\section{Le pouvoir des chaussettes // Puterea ciorapilor} nous n'éprouvons ni honte ni fierté

nu ne încearcă nici rușine nici mîndrie

Thus, in the target text, the concept of shame is positioned at the crossroads between a paradigmatic axis, which no longer functions by the principles of selection, of a sau... sau, but of a și... și, and a syntagmatic 
axis, where the goal of combinations is lexical richness. However, the specialized text determined by its dominant - namely by a certain hierarchy of functions, as defined before Katharina Reiss by Roman Jakobson $(1960$, p. 353; 1963) in the '60s as the determining factor of the message profile itself-is not defined by the projection of the principle of equivalence from the axis of selection to the axis of combination, as it occurs in poetry. On the contrary, in this case it is defined by the "sequential [combination] of equivalent units" (Jakobson, 1960, p. 358): once the concept is delimited, the selection is far more rigid, and the combination follows more or less the rules of mathematical equations. Thus, substitution-specific to the paradigmatic axis-does not function as such in a specialized text; it does not replace the "central" term of a terminological grid, but it completes it.

This may explain why the translation of shame in expressive texts follows another logic, where equivalence can become the rule or, in any case, also according to Roman Jakobson, "the constitutive principle of the sequence" (Jakobson, 1960, p. 358). Three examples taken almost randomly (actually, randomly from the things I have read recently) may prove this.

\section{By way of conclusion: on the false freedom of the translator}

I have mentioned - at the beginning of my analysis - that the translator hesitated to construct a grid of specialized terms symmetrical to the one in the source text. I have underscored his reticence to the neologizing of the adjective rusinos [shameful]; the price to pay was the dispersion of the terminological grid into a multitude of para- and periphrastic structures, a fluctuation that contravenes flagrantly the intentionality of the source text. However, maybe his reticence has another explanation, too: cultural, literary and historical. An entire lexicon borrowed from the French (that Pompiliu Eliade also mentioned), which I invoked at the beginning of this study would rapidly be eliminated, in late nineteenth century, from the Romanian language lexicon. Actually, the vocabulary of the characters within the plays of Alecsandri and Caragiale, which reflected the state of the Romanian society of their time, stands to prove the passage from the euphorizing Frenchisms of Chirița to their decadence in the lexicon of Caragiale's characters. The vocabulary - today almost indecipherable-of Franțuzitele by Constantin Faca, and then of the idiolect of Chirița by Vasile Alecsandri (that almost became an idiom) also increasingly hard to comprehend (insofar as the comic character is based on a French-speaking trend today in a state of accelerated desegregation) soon lost the "mark of prestige". The new jargon, practiced daily by Caragiale's characters, now comprising loan words turned into Romanian, would degrade into all sorts of deformations once it was integrated into the world of Bucharest slums. The conscience of their symbolic value in Chirița's world would fully dissipate; the language was not able to assimilate, but only to distort them.

Maybe the same thing happened with the couple ruşinoasă - a ruşina, which in Romanian acquired a comic and pejorative connotative load, which led to all the hesitations in their transposition. I remind here that Veta is ruşinoasă and that neither she nor her sister must be ruşinate: actually, the translators of Caragiale's plays into French (by the way, they are far from novice; see Caragiale, 1994) avoided la honte. They constantly transposed ruşinea by pudeur or gêne: the adjective-verb couple of the same family is not mentioned; the translators oscillated between gêner, a mitigating tem, and ne pas la faire rougir.

Ca să nu le rușinez, știi cum e Veta mea... rușinoasă

Ca sa nu le rușinezi...

Știi cum e Veta mea... - Rușinoasă, mie-mi spui?

să n-o rușinez

Rușinoasă, mie-mi spui?

Rușinoase... mie-mi spui?
... histoire de pas les gêner. Vous savez comment qu'elle est, ma Véta, elle a de la pudeur. Pour pas les gêner...

Vous savez comment qu'elle est, ma Véta...

- Pudique! À qui le dites-vous!

pour ne pas la faire rougir

Pudique! À qui le dites-vous!

Pudiques, à qui le dites-vous? 
Far more recently, the successful novel of the Iași-based writer Dan Lungu, Sînt o babă comunistă!, was translated into French by Laure Hinckel. I believe to have selected all the occurrences (not many) of the term ruşine and I was curious to see the extent to which this term was featured literally in the French translation. I was not surprised to note the translator's freedom: faced with a literary text, the hierarchy of dominants had changed. I was able to find-among the translation techniques, this time around justified, though sometimes disputable-her translational intention of transforming equivalence into a "constitutive principle" (Jakobson, 1960, p. 358) a of the translation. Where the Romanian text reads neobrăzat (a term featured inadequately in Cyrulnik's Romanian version), the translator chooses a phrasing that is actually very far from the concreteness and register of the original:

Ba chiar eu am fost mai neobrăzată, dacă mă Je crois bien qu’à l'époque j'ai fait un choix gîndesc bine. (p. 7) encore plus radical. (p. 9)

"Lipsa de obraz", expressed in the source text in a very familiar register and very concrete from a metaphorical perspective, is however translated into French using a lexicon which would better suit a different environment and context:

Auzi, știi ce, ești nesimțit. N-ai cherestea, zău! Bon, tu sais, tu n'as aucun savoir-vivre. Pas (p. 145) dégauchi pour deux sous, ma parole! (p. 141)

Neruşinarea is transposed by insolence, again a more abstract term, which belongs to a more formal register:

Uneori gobăile sînt așa de neruşinate, că se Parfois ces ornies sont d'une insolence incroybagă în cotețul porcului să-i fure mîncarea. able. Elles vont jusqu'à entrer dans la soue du (p. 71) cochon pour lui piquer son repas. (p. 70)

The wish to avoid the direct translation of face pe rusinata determines-probably due to the translator's sloppiness-an unpleasant but obviously unintentional repetition:

Învățătoarea dă ochii peste cap, face pe ruşinata, spune că iș̣i face doar datoria, că nu e nevoie, dar, dacă ei totuși insistă, fiindcă tot se pregătește să meargă la o nuntă, o brățară modestă ar fi un cadou potrivit. (p. 125)
La maîtresse lève les yeux au ciel, fait sa modeste, dit qu'elle ne fait que son devoir, que ce n'est pas nécessaire, mais que si nous insistons il se trouve quelle doit se rendre à un mariage et un modeste bracelet serait un cadeau approprié. (p. 122)

The rest of occurrences of ruşine are transposed directly, by correspondence:

Cu ce obraz călcam eu din nou în ogradă? Ce ruşine! (p. 118)

În momentele de slăbiciune sînt gata să-mi pun hainele înapoi în dulap, dar știu foarte bine că, de ruşine, peste cîteva zile o iau de la capăt. (p. 141)

Țucu a spus că din delicatețe. Fiindcă e prea ruşinoasă să aducă vorba de alimente [...] (p. 157)

Tre' să te gîndești la măritat, nu-i nici o ruşine... Simt că m-am înroşit... (p. 213)

Părea un cîine ruşinos, se ascundea... (p. 226)
Ce serait un coup à vouloir entrer dans un trou de souris! La honte! (p. 115)

Dans des moments de faiblesse, je suis toute prête à replacer mes vêtements dans le placard, mais je sais très bien que, de honte, dans quelques jours, je repars de zéro. (p. 138)

Tzucu disait que cétait par délicatesse. Parce qu'elle avait trop honte d'amener la conversation sur la nourriture [...] (p. 152)

Faut penser à te marier, il n'y a pas de honte... Je sens que je rougis... (p. 205)

On aurait dit que ce chien avait honte, il se cachait... (p. 217) 
Finally, a Romanian version of Le Petit Prince by Antoine de Saint-Exupéry $(1943,1971,1998)$ associates russinea, la honte-by particularizing broader and less concrete semantic spheres-with umilința, with timiditatea, jena, sfiala and ridicolul, almost as for pudoare in this text. Furthermore, the four occurrences for honte in the original text have turned into eight in the translated version.

Humiliée de s'être laissé surprendre à préparer un mensonge aussi naï, elle avait toussé deux ou trois fois, pour mettre le petit prince dans son tort. (p. 35)

Ça m'intimide... je ne peux plus... fit le petit prince tout rougissant. (p. 42)

Elle serait bien vexée, se dit-il, si elle voyait ça... elle tousserait énormément et ferait semblant de mourir pour échapper au ridicule. (p. 76)

Et les roses étaient bien gênées. - Vous êtes belles, mais vous êtes vides, leur dit-il encore. (p. 83)
Rușinată că se dăduse de gol cu o minciună urzită atît de stîngaci, tușise de cîteva ori, ca să arunce vina asupra micului prinț. (p. 11)

Mi-e rușine... nu mai pot... rosti micul prinț roșind. (p. 13)

„Tare s-ar mai socoti jignită, îşi zise el, dacă ar vedea una ca asta... nu s-ar mai opri din tuse și s-ar preface chiar că moare, ca să scape de rușine. (p. 24)

Și florile se rușinară. - Sînteți frumoase, dar sînteți deșarte, le mai spuse el. (p. 26)

In exchange, the physical manifestation of shame-roșeața, innroșirea - is transposed using poetizing terms: you can turn red of shame (not necessarily of shyness) or of pleasure, but a te imbujora de ruşine is rather inadequate. Actually, Saint-Exupéry's text plays with rather contrasting colours, handkerchiefs with red dots, the king's crimson, a man that was supposed to red (he is actually sometimes roșu, other times roșcovan in the Romanian version). Moreover, the Little Prince terns red many times (he also gets pale when he gets mad); this redness should have been preserved in the Romanian text, without alternating it with the poetic imbujorare, with the risk of committing mistranslations such as:

Il rougit, puis reprit: [...] (p. 30)

Le petit prince rougit de nouveau. Il ne répondait jamais aux questions, mais, quand on rougit, ça signifie «oui», n'est-ce pas? (p. 94)
Se îmbujoră-n obraji, pe urmă spuse mai departe: [...] (p. 10)

Micul prinț din nou se-mbujoră. El niciodată nu răspundea la întrebări, dar dacă te îmbujorezi înseamnă „da”, nu-i aşa? (p. 29)

All of these examples-randomly mentioned within the mixture of recent reads, not following a coherent program of elaborating a corpus-justify the grid elaborated by the skopos theory. At the same time, however, they show what I called the "false" freedom of the translator who has a double task to fulfil in his translational process. The first is to transpose a text into a target language, while the second is to determine to category to which the text pertains (thus to construct a typology for it in the meanwhile). Hence, a translator's freedom is limited not only by history, by the horizon of expectation of his period, by the translational traditions (also historically determined), but also by the imperative of reconstructing the same type of text in the target language. The translator is thus never completely isolated or alone: his endeavour will or will not be successful also depending on his capacity of deciphering correctly the intention of the text to translate. 


\section{Bibliography}

Almonte, C. (2011). Comentario de libros: Morirse de vergüenza, în „Psiquiatría universitaria”, p. 387-388, [online].

Berman, A. (1999). La traduction et la lettre ou l'auberge du lointain, Seuil, Paris.

Caragiale, I.L. (1959). Teatru, Editura de Stat pentru Literatură și Artă, București.

Caragiale, I.L. (1994). Théâtre, adaptare din limba română de Eugène Ionesco și Monica Lovinesco, L’Arche, Paris.

Cassin, B. (éd.) (2004). Vocabulaire européen desphilosophies. Dictionnaire des intraduisibles, Éditions du Seuil/Le Robert, Paris.

Cornea, P. (1972). Ce ne dezvăluie traducerile de la sfîrşitul sec. al XVIII-lea și începutul secolului al XIXlea, în Originile romantismului românesc, Minerva, București.

Crașoveanu, D. (2002). Categorii sintactice necircumstanțtiale, Editura Mirton, Timișoara.

Cyrulnik, B. (2010a). Mourir de dire. La Honte, Odile Jacob, Paris.

Cyrulnik, B. (2010b). J'ai connu la honte, interviu de Émilie Lanez, în „Le Point”, 2 sept., [online].

Cyrulnik, B. (2011a). Scham. Im Bann des Schweigens - Wenn die Seele vergiftet, trad. Maria Buchwald și Andrea Alvermann, Präsenz Kunst und Buch Verlag, Hünfelden.

Cyrulnik, B. (2011b). Morirse de vergüenza. El miedo a la mirada del otro, trad. Maria Pons Irazazábal, Editura Debate, Barcelona.

Cyrulnik, B. (2012). Mai bine mor decât să spun. Ruşinea, trad. Valentin Protopopescu, Editura Trei, București.

Cyrulnik, B. (2013). J'ai surmonté la honte, ce poison de l'âme, interviu de Isabelle Vial, în „Pèlerin”, nr. 6673, 16 iul., [online].

Freud, S. (1900). Die Traumdeutung, în Studienausgabe, S. Fischer Verlag, Frankfurt am Main.

Freud, S. (1909). Analyse der Phobie eines fünfjährigen Knaben, în Studeineausgabe, vol. 8, S. Fischer Verlag, Frankfurt am Main. Freud, S. (2010a). Opere esențiale. Interpretarea viselor, vol. 2, trad. Roxana Melnicu, Editura Trei, București.

Freud, S. (2010b). Micul Hans. Analiza fobiei unui băiețel de cinci ani, în Opere esențiale. Nevroza la copil, vol. 8, trad. Rodica Matei și Ruxandra Hosu, Editura Trei, București.

Gehring, P. (2011). Eine Art innere Gefangenschaft, în „Frankfurter Allgemeine Zeitung”, 5 oct., [online].

Graur, Al. (1973). Gramatica azi, Editura Academiei, București.

Ionescu, G. (1981). Cîteva repere, în Orizontul traducerii, Univers, București.

Jakobson, R. (1960). Linguistics and Poetics, în Sebeok, Th. A. (ed.), Style in Language, Wiley, New York.

Jakobson, R. (1963). Linguistique et poétique, în Essais de linguistique générale, traducere din limba engleză de Nicolas Ruwet, Minuit, Paris.

Janin, Cl. (2003). Pourune théorie psychanalytique de la honte (honte originaire, honte des origines, origines de la honte), în „Revue française de psychanalyse", vol. 67, nr. 5, p. 1657-1742, Crossref.

Kinston, W. (1983). A theoretical context of shame, în „International Journal of Psycho-Analysis”, nr. 64, p. 213-226.

Ladmiral, J.-R. (1989). Pour une philosophie de la traduction, în „Revue de métaphysique et de morale. La traduction philosophique", nr. 1, Éditions Armand Colin, Paris.

Ladmiral, J.-R. (1994). Traduire: théorèmes pour la traduction, Éditions Gallimard, Paris.

Ladmiral, J.-R. (1998). Principes philosophiques de la traduction, în Encyclopédie philosophique universelle, ediție coordonată de André Jacob, vol. IV, PUF, Paris.

Lungu, D. (2007). Sînt o babă comunistă!, Editura Polirom, Iași.

Lungu, D. (2008). Je suis une vieille coco!, traducere din limba română de Laure Hinckel, Jacqueline Chambon, Paris.

Popovici, D. (1977). Studii literare. III, Dacia, Cluj-Napoca.

Reiss, K. (2002). La critique des traductions, ses possibilités et ses limites, trad. Catherine Boquet, Artois Presses Université.

Ricœur, P. (2005). Despre traducere, trad. și studiu introductiv de Magda Jeanrenaud, postfață de Domenico Jervolino, Polirom, Iași.

Rosenblum, R. (2000). Peut-on mourir de dire? Sarah Kofman, Primo Levi, în „Revue française de psychanalyse”, LXIV, nr. 64, Crossref.

Saint-Exupéry, A. de (1943). Le petit prince, Reynal \& Hitchcock, Paris.

Saint-Exupéry, A. de (1971). The Little Prince, traducere din limba franceză de Katherine Woods, Harcourt, New York.

Saint-Exupéry, A. de (1998). Micul prinț, traducere din limba franceză de Benedict Corlaciu, Editura RAO, București.

Semprun, J. (1994). L'écriture ou la vie, Gallimard, Paris.

Tristán, R.M. (2011). Claves para nómorirse de vergüenza, în „El Mundo”, 13 nov., [online]. 